DOI 10.47315/archives2020.323.086

УДК 94(477+438)»192»:[341.7+355]:930.25(438)

Ігор Срібняк

доктор історичних наук, професор, завідувач кафедри всесвітньої історії історико-філософського факультету,

Київський університет імені Бориса Грінченка ORCID: https://orcid.org/0000-0001-9750-4958

\title{
3 ІСТОРІЇ ДІЯЛЬНОСТІ УКРАЇНСЬКОЇ ВІЙСЬКОВОЇ ДИПЛОМАТІЇ В ПОЛЬЩІ У 1920 РОЦІ (за документами Центрального військового архіву Польщі)
}

\begin{abstract}
Анотація. Мета статті полягає у залученні до наукового обігу неопублікованих архівних документів, які зберігаються у Центральному військовому архіві Польщі (Centralne Archiwum Wojskowe). Останні являють собою цінне джерело для відтворення основних напрямів діяльності Української військової місії в Польщі (травень - жовтень 1920 р.). Методологія дослідження передбачає дотримання принципів історизму, антропологізму, цивілізаційного, сенергетичного і системного підходів, застосування методів аналізу і синтезу, компаративістичних методик. Наукова новизна статті зумовлена високою джерельною вартістю згадуваних архівних документів, що містять значну кількість прізвищ старшин та військових урядовців Армії УНР, які прибували до Варшави у різних службових справах. Також у наказах зафіксована інформація про численні відрядження членів Місії, інколи із зазначенням мети і місця їхньої подорожі. В окремих випадках у наказах Місії відтворювалися фрагменти (або й повністю) директив вищих військових інституцій Армії УНР. Висновки. Аналіз наказів, проведений в рамках цієї статті, засвідчує, що за весь час свого існування Українська військова місія виконала величезний обсяг роботи, яка полягала, насамперед, у забезпеченні процесу поповнення особового складу Армії УНР. Разом із тим, іiі члени докладали всіх зусиль для налагодження поставок зброї для Дієвої армії, провівши 3 цією метою ряд переговорів із зацікавленими у цьому представниками урядів європейських країн та ділових кіл. Діяльність Української військової місії стала одним із найяскравіших епізодів у польсько-українській військово-політичній співпраці 1920-х - 1930-х років, давши кращі приклади кооперації зусиль двох країн - Польщі та УНР - перед смертельною загрозою з боку більшовицької Росії. Весь час свого існування Місія залишалася центральною зв'язковою ланкою між військовими відомствами і збройними силами двох країн, причинившись доформування у більшості представників польського
\end{abstract}


військового проводу позитивного сприйняття Армії УНР та іiї бойового потенціалу.

Ключові слова: Українська військова місія; наказ; кур'єр; відрядження; Армія УНР; Польща; польсько-українська співпраця.

Новітня фаза вивчення специфіки польсько-української військово-політичної співпраці у 1920 р. вже має свою досить тривалу протяжність, бо ії̈ було започатковано ще у другій половині 1990-х років. У цей час зусиллями як українських, так і польських істориків було підготовлено цілу низку праць, що дозволило досить повно представити цю проблему для наукового загалу ${ }^{1}$. Важливим було й те, що справа дійшла до кооперації зусиль науковців двох країн².

Ці праці, вочевидь, не вичерпували всіх аспектів проблеми, відтак вона й у подальшому перебувала у полі уваги дослідників. Зусиллями молодшої плеяди істориків України, зокрема, були цілісно відтворені особливості функціонування військової секції при Українській дипломатичній місії у Варшаві та створеної на їі основі Української військової місії в Польщі ${ }^{3}$. Ці 2 розвідки були підготовлені на основі залучення широкого кола джерел та до сьогодні зберігають свою актуальність, являючи собою підгрунтя для проведення подальших розшуків у цій царині.

Провівши значну пошукову роботу в архівах кількох країн, до наукового розроблення різних аспектів українсько-польської військової кооперації у 1920 р. вагомо долучився історик А. Руккас ${ }^{4}$. Окреслена проблематика не втрачала своєї актуальності й в подальшому, знову ставши предметом обговорення польських і українських істориків

1 Срібняк I. Симон Петлюра на чолі держави та війська. До питання про польсько-українські взаємини 1919-1920 років // Збірник праць другого конкурсу петлюрознавців України. Київ, 1995. С. 137-164; Karpus Z. Formowanie oddziałów ukraińskich w Polsce w latach 1919-1920 // Polska i Ukraina. Sojusz 1920 roku i jego następstwa. Red. Z. Karpus, W. Rezmer, E. Wiszka. Toruń, 1997. S. 235-244; Karpus Z. Jeńcy i internowani rosyjscy i ukraińscy na terenie Polski w latach 1918-1924. Toruń, 1997. 209 s.; Karpus Z. Wschodni sojusznicy Polski w wojnie 1920 roku. Oddzialy wojskowe ukraińskie, kozackie i bialoruskie w Polsce w latach 1919-1920. Toruń, 1999. 230 s.

2 Kарпус 3., Срібняк I. Формування з'єднань Армії УНР у Польщі в 1920 рр. // Український історичний журнал. 2000. № 1. С. 81-89.

3 Руккас A., Ковальчук М. Діяльність військової секції при Українській дипломатичній місії у Варшаві (грудень 1919 р. - липень 1920 р.) // Українська старовина. 2003. № 5(353). С. 128-156; № 6(354). С. 150-158; Ковальчук М. Українська військова місія в Польщі (липень-листопад 1920 р.) // Україна дипломатична. 2005. Вип. 6. С. 382-406.

4 Руккас А. О. «Разом з польським військом...»: Армія Української Народної Республіки 1920 р. (структура, організація, чисельність, уніформа). Ніжин, 2013. 480 с. 
у рамках влаштованих Посольством Польщі в Україні наукових форумів 2018 і 2019 років 5 .

Зараз - $з$ огляду на нововіднайдені в польських архівах документи - існує потреба продовжити накопичення фактологічної інформації про діяльність Української військової місії в Польщі. 3 цією метою було опрацьовано комплекс документів, які зберігаються в Центральному військовому архіві (Centralne Archiwum Wojskowe). Ці документи являють собою цінне джерело для відтворення основних напрямів діяльності згадуваної Місії. Власне йдеться про колекцію наказів «Секції по військових справах при Українській Дипломатичній Місії в Речі Посполитій Польській» (30 квітня - 20 травня 1920 р. $)^{6}$ i «Українській Військовій Місії в Речі Посполитій Польській» (23 серпня - 23 жовтня 1920 р. $)^{7}$.

Накази регламентували внутрішню життєдіяльність секції і Місії, маючи спочатку позначку «стройова («муштрова») частина» (для секціï) або «загальна частина» (для Місії). Вони містять значну кількість прізвищ старшин та військових урядовців Армії УНР, які прибували до Варшави у різних службових справах. Також у наказах зафіксована інформація про численні відрядження членів Місії, інколи із зазначенням мети і місця їхньої подорожі. В окремих випадках у наказах Місії відтворювалися фрагменти (або й повністю) директив вищих військових інституцій Армії УНР.

Всі аналізовані у статті документи є копіями наказів. Вони засвідчені підписом начальника канцелярії секції і місії сотника Ю. Осецького (оригінали наказів підписувалися одноосібно генерал-поручником В. Зелінським). 3 огляду на їхню «копійність», текст деяких наказів $є$ згасаючим, в окремих випадках його можна відчитати зі значними зусиллями, а подекуди - взагалі неможливо. Накази надруковані на стандартних аркушах паперу жовтуватого (з огляду на столітній вік документів) кольору.

5 Срібняк I. Військова співпраця УНР та Польської Республіки у другій половині 1919-1920рр.: організаційно-мобілізаційний аспект // Польськоукраїнська військова співпраця протягом історії : матеріали конференції. Київ: Дух і Літера, 2018. С. 151-176; Руккас А. Польсько-український військовий союз 1920 р. // Там само. С. 202-233; Шумило М. Генеза союзу. Відносини Української Народної Республіки з Польщею (січень 1919 - квітень 1920 рр.) // Україна і Польща: шляхами міждержавних взаємин. Зб. наук. праць 3 нагоди 100-річчя встановлення польсько-українських дипломатичних відносин / наук. ред. І. Матяш; вип. ред. В. Собіянський; пер. 3 пол. К. Москалець. Київ, 2019. С. 36-53; Руккас А. Створення та діяльність органів військово-дипломатичного представництва УНР в Польщі (1919-1921рр.) // Там само. С. 89-107.

6 WBH CAW (Wojskowe Biuro Historyczne. Centralne Archiwum Wojskowe). Zespól Akt «Sprzymierzona Armia Ukraińska» (далі - «SAU»). Sygnatura I. 380.1.43.

\footnotetext{
7 Tам само. Zespól Akt «SAU». Sygnatura I. 380.1.44.
} 


\section{$* * *$}

Як уже зазначалося, завдяки виходу вже згадуваних публікацій А. Руккаса і М. Ковальчука процес створення та подальшої діяльності секції з військових справ при дипломатичній місії УНР у Польщі та Української військової місії є вже достатньо проясненим, що робить недоцільним наведення тут докладної про це інформації. Але все ж таки варто побіжно окреслити основні віхи іiі діяльності. Військова секція при Українській дипломатичній місії в Польщі була заснована 12 грудня 1919 р. на виконання наказу № 862 головного отамана Військ УНР С. Петлюри. Першим ії̈ начальником був призначений генерал М. Юнаків, який виконував у цей час й обов'язки начальника штабу головного отамана. Нездатність останнього налагодити ефективну комунікацію 3 керівниками польського військового відомства спонукала С. Петлюру усунути його з посади керівника секції та призначити іiі начальником генерал-поручника В. Зелінського.

Після цього секція була реорганізована та кількісно збільшена, a енергійні дії іiі начальника і його підлеглих дозволили розпочати процес формування 1-ої (майбутньої 6-ої Січової) дивізії, а пізніше й 2-ої (майбутньої 3-ої Залізної) дивізії Армії УНР. При цьому секція в цьому процесі грала ключову роль, організувавши вишкіл у Ланцуті вояків-українців із числа тих, хто перебував у таборах полонених та інтернованих на терені Польщі. Крім того, заходи співробітників секції уможливили залучення до лав цих формацій українських вояків, які перебували на Поділлі. Завдяки інтенсивній організаційно-мобілізаційній роботі членів секції згадувані дивізії були укомплектовані (хоча й неповністю), всі їхні потреби покривалися польською інтендантурою ${ }^{8}$.

Після підписання Варшавської угоди (квітень 1920 р.) для союзників (Польщі та УНР) стало можливим розпочати широку наступальну операцію, що мала своїм завданням звільнення Правобережної України від більшовицьких військ та повернення уряду УНР до Києва. Невдовзі після відкриття воєнних дій Ставка головного отамана Військ УНР перемістилася на терени України. Перед своїм виїздом (останні числа квітня 1920 р.) С. Петлюра позитивно оцінив роботу секції, висловивши сподівання в тому, що іії співробітники й надалі працюватимуть віддано і з повною самопожертвою. У свою чергу голова секції генерал-поручник В. Зелінський закликав своїх підлеглих «до праці об'єднаної однією думкою і взаємним довіррям і допомогою один одному» ${ }^{9}$.

8 Руккас А., Ковальчук М. Зазнач. твір.

9 WBH CAW. Zespól Akt «SAU». Sygnatura I. 380.1.43. («Наказ Секції по військових справах при Українській Дипломатичній Місії в Речі Посполитій Польській» № 101 від 30 квітня 1920 р., засвідчений підписом начальника iï канцелярії сотника Ю. Осецького). 
Від’їзд Ставки відразу збільшив обсяг канцелярської праці для секції (всі вихідні документи мали відтоді готуватися у письмовому вигляді), а також змусив залучити більшу кількість кур'єрів для зв'язку зі Ставкою. 3 огляду на це В. Зелінський зобов'язав усіх співробітників секції «звернути пильну увагу на зміст паперів [...] як з боку їх повної відповіді по кожному питанню, так і обгрунтованности їх, не кажучи вже про їх стіль і орфографію». Для забезпечення цього всі вихідні документи мали візуватися референтами секції або начальником канцелярії секції сотником Ю. Осецьким ${ }^{10}$.

3 метою забезпечення максимальної ефективності роботи секції В. Зелінський зобов'язав начальників іiі відділів до 13 травня підготувати «сводку праці по референтурам» із викладом обговорюваних реалізованих питань. Загальне зведення про поточну роботу секції було передано для ознайомлення головному отаманові С. Петлюрі та військовому міністру уряду УНР В. Сальському. Крім того, їм було наказано вести щоденник власної праці у відділах, який мав щотижнево переглядатися В. Зелінським ${ }^{11}$.

Найважливішим завданням, яке стояло перед секцією у цей час, було забезпечення поповнення Дієвої армії, бо її участь у наступальних операціях союзних військ супроводжувалася бойовими втратами. Крім того, надзвичайно важливим було завдання збільшення чисельного складу Військ УНР шляхом творення нових частин та 3'єднань. Тому секція докладала всіх зусиль для цього, відправляючи своїх представників до Німеччини, де все ще продовжували перебувати колишні полонені вояки-українці часів Першої світової війни. Аби «налагодити найскорше повернення на Україну, через Польщу, перебуваючи у Нiмеччині полонених українців, як старшин, так і козаків», до цієї країни був відряджений хорунжий П. Омельченко. Йому доручалося «об'їхати всі табори, де такі перебували, для ознайомлення з їхнім життя i потребами», після чого «виробити 3 представниками урядів: Українського, Німецького і Польського - порядок перевозки полонених на Україну» ${ }^{12}$.

Також йому доручалося «вияснити, що за військове майно придбано в Німеччині для України, його якість і вартість, дбаючи аби придбане відповідало сучасним потребам Української Армії». Насамкінець хорунжому П. Омельченку доручалося «брати участь у всіх комісіях

10 WBH CAW. Zespól Akt «SAU». Sygnatura I. 380.1.43. («Наказ Секції по військових справах при Українській Дипломатичній Місії в Речі Посполитій Польській» № 101 від 30 квітня 1920 р., засвідчений підписом начальника іiї канцелярії сотника Ю. Осецького).

11 Там само. Zespól Akt «SAU». Sygnatura I. 380.1.43. («Наказ Секції...» № 101 від 30 квітня 1920 р.).

12 Там само. Zespól Akt «SAU». Sygnatura I. 380.1.43. («Наказ Секції...» № 112 від 14 травня 1920 р.). 
по закупці для України військового майна, звертаючи увагу на його якість, і прискорити відправку цього майна через Секцію Військов[их] Справ при У.Д.М. в Польщі, в розпорядження Військового Міністерства У.Н.Р.» ${ }^{13}$.

Цим же наказом В. Зелінський зобов'язав Помічника військового референта секції сотника Гудиму та поручника Я. Горшківського виїхати до Кракова і Домб’є «з метою перевести регістрацію Українським воякам, служившим в частинах «Добрармії» (йдеться про Добровольчу армію - I. С.), склавши їм списи, з поміткою певности і здібности кожного 3 них для служби в Армії У.Н.Р.» ${ }^{14}$.

3 тексту цього ж наказу можна дізнатися про приїзд із Ланцута до Варшави представника 6-ої Січової дивізії (його прізвище подано нерозбірливо - I. С.), який мав за кілька днів виїхати до Естонії у справах організації перевезення українських старшин і козаків, які там перебували, в Україну. Напередодні до Варшави з цією ж метою прибув секретар Українського національного комітету в Естонії хорунжий В. Онопрієнко ${ }^{15}$.

Крім підготовки поповнення для Дієвої армії, секція займалася й питаннями забезпечення українського вояцтва одностроями та іншою військовою амуніцією (за клопотаннями командирів дивізій Армії УНР). 3 цією метою В. Зелінський розпорядився утворити при секції тимчасову закупочну комісію в складі помічника референта 3 господарських справ підполковника Піленка (голова), референта в справах полонених сотника Г. Драченка і поручника Я. Горшківського (члени). До завдань цієї комісії було віднесено укладення «всіх умов і контрактів 3 подрядчиками», які також мали бути завізовані референтом із господарських справ секції полковником М. Бондарівським та затверджені начальником секції ${ }^{16}$.

До секції стікалася вся найважливіша інформація військово-політичного змісту, яка мала негайно передаватися до Ставки головного отамана Військ УНР. Значна їі частина передавалася до секції довіреними посланцями чільних українських дипломатів та голів українських організацій з різних європейських країн. Останні прибували до секції ледь не щодня та жадали відомостей про хід визвольного походу польської та української армій (серед них - кур'єр із Парижу від графа М. Тишкевича, кур'єр з Естонії хорунжий В. Онопрієнко та ін. ${ }^{17}$.

13 Там само. Zespól Akt «SAU». Sygnatura I. 380.1.43. («Наказ Секції...» № 112 від 14 травня 1920 р.).

14 Там само. Zespól Akt «SAU». Sygnatura I. 380.1.43. («Наказ Секції...» № 112 від 14 травня 1920 р.).

15 Там само.

16 Там само.

17 WBH CAW. Zespól Akt «SAU». Sygnatura I. 380.1.43. («Наказ Секції...» № 114 від 15 травня 1920 р.). 
У свою чергу, це вимагало негайного відрядження співробітників секції на звільнені українські землі, причому вони в цих подорожах виконували як правило цілу низку відповідальних доручень В. Зелінського. У середині травня 1920 р. із такою місією до України виїхав ад’ютант начальника секції поручник О. Давидович-Мірза. Він мав, зокрема, відвідати С. Петлюру «з докладом державної ваги», передати листи В. Зелінського до військового міністерства УНР та головної управи Генерального штабу Армії УНР у Вінниці, а також передати деякі документи начальнику 6-ої Січової дивізії полковнику М. Безручку в Києві, представникові українського командування при штабі головної команди Військ Польських полковнику Капустянському (Житомир), командиру запасної бригади генерал-хорунжому I. Феденяк-Білинському в Бердичеві. Всіх цих військових посадовців належалося поінформувати «про справи військові за кордоном», а також отримати від них дотичну інформацію, після чого ад’ютант мав повернутися до Варшави. За деякий час до Вінниці був відряджений підполковник Піленко, який мав вручити С. Петлюрі листа від графа М. Тишкевича та зробити йому «усний доклад» із питань «військово-економічних і господарчих Державної ваги» ${ }^{18}$.

Масштабні воєнні дії, які проводилися союзниками проти більшовицької Росії влітку 1920 р., їх складний перебіг (здобуття Києва та його залишення після прориву в запілля союзних армій 1-ої Кінної армії, запеклі бої під час подальшого відступу) вимагали підвищення ефективності військової співпраці між Армією УНР і Військом Польським. 3 цією метою 15 липня 1920 р. на базі військової секції була створена Українська військова місія на чолі з В. Зелінським. Таке підвищення статусу означало й розширення кола іiї завдань, до числа яких належали: встановлення контактів із військовими дипломатами, які були акредитовані в Польщі; закупівля військового майна в Польщі та за кордоном, інформування польського суспільства про боротьбу, яку провадила Армія УНР спільно з Військом Польським. Місія й надалі мала опікуватися ходом підготовки поповнень для Дієвої армії, використовуючи для цього Збірну станицю Армії УНР у Ланцуті ${ }^{19}$.

Штати Місії були регламентовані відповідним законом, що був ухвалений Радою народних міністрів УНР (і оголошений в наказі Військовій місії № 50 від 23 серпня 1920 р.). Його підписали прем’єр-міністр уряду УНР В. Прокопович і військовий міністр В. Сальський, там же було й визначено джерело покриття видатків Місії - військовий фонд уряду УНР. Закон набув чинності з 1 липня 1920 р., але був затверджений головним отаманом С. Петлюрою лише 4 серпня цьо-

18 WBH CAW. Zespól Akt «SAU». Sygnatura I. 380.1.43. («Наказ Секції...» № 114 від 15 травня 1920 р.).

19 Ковальчук М. Зазнач. твір. 
го ж року. У додатках до «Закону...» був затверджений також персональний склад Мiсiї ${ }^{20}$ та його внутрішня структура. Місія складалася 3 4-х відділів: організаційний і навчання війська, інформаційний, національно-просвітницький і організації полонених та господарський.

До функцій відділу організаційного і навчання військ (I-го) належали всі справи з «організації запасових або польових військових частин, як на терені Польщи, так і по за межами їі», а також встановлення їх штатів у відповідності до директив Генерального штабу Армії УНР. Його співробітники «реферували всі організаційні проекти і справи», забезпечували «частини статутами, підручниками і мапами», організовували «видання військових підручників чужих мов, згідно вказівок» головної управи Генерального штабу, підтримували зв'язок з організаційним та оперативним відділами Генштабу Польської армії.

Інформаційному (II-му) відділу було доручено перебувати у постійному зв'язку із закордонними місіями та інформаційним відділом Генштабу Польської армії. Його співробітники мали проводити «збір, учот і стеження» за всією інформацією військового і політичного змісту, подаючи ці відомості вищим військовим та політичним структурам УНР. До компетенції відділу була віднесена реєстрація всіх осіб, які прибували до Місії; стеження «за політичним життям Українських чинників за кордоном»; реферування преси та укладання на основі цього аналітичних звітів військового характеру; «евіденція всіх бажаючих вступити до Української Армії».

Відділ національно-просвітній і організації полонених (III-й) займався організацією «національно-просвітної справи по таборам і в

20 WBH CAW. Zespól Akt «SAU». Sygnatura I. 380.1.44. («Наказ Українській Військовій Місії в Речі Посполитій Польській, № 50 від 23 серпня 1920 р. за підписом начальника канцелярії сотника Ю. Осецького). Склад Військової місії: генерал-поручник В. Зелінський (голова), поручник А. Овсієвський (булавний старшина для доручень), поручник О. Давидович-Мірза (ад’ютант), генштабу підполковник М. Дідковський (референт, начальник I-го відділу), хорунжий Ф. Шпачинський (старшина для доручень), сотник В. Стрижак (референт, начальник II-го відділу), поручник Я. Горшківський (помічник референта), хорунжий П. Котович (старшина для доручень), сотник Г. Драченко (референт, начальник III-го відділу), полковник М. Бондарівський (референт, начальник IV-го відділу), хорунжий Паторжинський (помічник референта), сотник П. Кащенко (скарбник), хорунжий I. Чудненко (старшина для доручень), лікар Е. Мерковський, сотник Ю. Осецький (начальник канцелярії місії), хорунжий А. Булгаків (комендант), урядовець Антонович (перекладач із польської), Савінський (перекладач із французької та англійської), урядовець Цимбалюк (діловод), хорунжий Грунський (діловод), Мещеряк (кур'єр), Бачинська, Аврус, Захар'євич, Доброчинська (перекладачки з французької). Через скорочення штатів зі складу місії були виключені сотник М. Веденський (юристконсульт) і хорунжий П. Омельченко (обер-старшина для доручень). Урядовець Валіцький (секретар місії) за власним бажанням відбув на фронт. 
військових частинах на терені Польщі», постачанням таборів і військових частин Армії УНР літературою та організацією «видання брошур по національно-просвітнім справам», обліком «полонених, інтернованих і конфінованих на терені Польщі». Відділ мав також налагодити «національну організацію полонених по таборам», підготувавши їх у такий спосіб «до вступу у військо». 3 цією метою його співробітники мали надавати допомогу в заснуванні товариств, громад, просвітніх організацій в таборах. Крім цього, відділ також опікувався збиранням інформації «про стан Українських полонених по іншим державам», дбаючи про їх повернення в Україну.

Господарчий (IV-й) відділ був покликаний сприяти «постачанню Української Армії та всіх частин і інституцій запілля усіма видами задоволення через Польську Владу». До його функцій, зокрема, належала закупівля (через торгівельно-закупочну місію) потрібної Війську УНР зброї та військової амуніції, проведення матеріально-фінансових взаєморозрахунків із польською військовою владою. Співробітники відділу забезпечували «організацію військової господарки» та здійснювали нагляд «за правильним проводженням господарства во внов формуемих частинах» на теренах Польщі та, зокрема, у Ланцуті. Задля виконання вказаного кола завдань відділ мав підтримувати постійний зв'язок із головною управою постачання військового міністерства УНР ${ }^{21}$.

Слід відзначити, що така структура була оптимальною та дозволяла Місії виконувати покладені на неї завдання у повному обсязі. Маючи у складі Місії достатню кількість кваліфікованих та відданих своїй справі співробітників, В. Зелінський міг оперативно та ефективно реагувати на всі виклики, які постали перед Польщею і УНР через несприятливий для останніх розвиток подій на фронті. Зокрема, саме через Місію інтендантура Армії УНР отримувала 3 польських військових складів зброю та амуніцію, які передавалися у розпорядження окремих ії частин та з'єднань Дієвої армії. 3 метою більшої централізації цього процесу та пропорційності в розподілі військового майна і зброї між дивізіями, військове міністерство УНР у серпні 1920 р. вирішило змінити такий порядок i передати функцію отримання і розподілу власній головній управі постачання. Ініціатором цього власне виступив начальник згадуваної управи полковник М. Русіянов. Відтоді всі свої звернення комдиви мали адресувати до Місії через головну управу постачання військового міністерства УНР, а самі поставки військової амуніції вже передавалися до складів цієї структури ${ }^{22}$.

${ }^{21}$ WBH CAW. Zespól Akt «SAU». Sygnatura I. 380.1.44. («Наказ...» № 50 від 23 серпня 1920 р.).

22 Там само. Zespól Akt «SAU». Sygnatura I. 380.1.44. («Наказ...» № 52 від 24 серпня 1920 р.). 
Попри величезний обсяг роботи, що виконувався Місією, одним з їі пріоритетів завжди залишалося надання допомоги пораненим та інвалідам Армії УНР, які відзначилися у боях із більшовиками. Найяскравіше це проявилося тоді, коли до Варшави була доставлена тяжко поранена військова лікарка 46-го куреня 6-ої Січової дивізії Армії УНР поручник $\mathrm{X}$. Сушко ${ }^{23}$. Прагнучи належним чином підтримати ії під час лікування в одному з варшавських військових шпиталів, В. Зелінський звернувся 3 рапортом (№ 458 від 10 серпня 1920 р.) до головного отамана С. Петлюри, в якому клопотався про виділення ій грошової допомоги для «курортного лікування за кордоном». Головний отаман підтримав це клопотання, наклавши 17 серпня 1920 р. резолюцію такого змісту: «лікарь Сушко визначилась (треба: відзначилася - I. C.) за час боротьби за Українську незалежність цілковитою відданістю справі і визначним героїзмом, - а тому асигнування 35.000 марок [польських] є реалізація обовязку держави і іï влади до одної з кращих дочок іiі. Суму асигновки затверджую» ${ }^{24}$.

Це був час, коли ситуація на польсько-більшовицькому фронті почала змінюватися на користь Польщі та УНР, після чого польська сторона отримала можливість збільшити військово-технічну допомогу своєму союзнику. 24 серпня 1920 р. до Варшави прибув начальник дорожньо-технічного відділу Генштабу Армії УНР сотник М. Сажин, який був уповноважений до отримання рухомої майстерні та панцерних потягів. Протягом серпня - першої половини вересня 1920 р. у Варшаві перебував військовий інженер полковник Виноградов, який невдовзі був приряджений до 6-ої польської армії ${ }^{25}$. Видатки під час їх перебування у польський столиці компенсувалися з коштів Місії шляхом виплати їм «добових».

Добові отримували усі військові кур'єри, які прибули до Варшави. Крім того, Місія оплачувала перебування у столиці й інших категорій вояцтва i, зокрема, тих вояків, які мали поповнити особовий склад автоколони 6-го технічного куреня, що формувалася у Варшаві. Для цього в кінці серпня 1920 р. до Місії зголосилися бунчужний О. Акушат, шофери Г. Гудиков, Д. Бамбула, шофер-механік I. Мартиненко і Й. Веховський, чотові М. Райно, М. Цуковський, козак А. Зільберцвальд Ще за кілька днів із Ланцуту до Варшави $з$ цією ж метою прибули

23 Докладн. про неї див.: Срібняк I. Непоказна звитяга (кілька епізодів 3 життя поручника Армії УНР, лікаря Христини Скачківської-Сушко, 19191925 рр.) // Наше життя. Нью-Йорк, 2018. T. LXXV. Ч. 1 (січень). С. 13-16.

${ }_{24}$ WBH CAW. Zespól Akt «SAU». Sygnatura I. 380.1.44. («Наказ...» № 52 від 24 серпня 1920 р.).

25 Там само. Zespól Akt «SAU». Sygnatura I. 380.1.44. («Наказ...» № 52 від 24 серпня 1920 р., «Наказ...» № 111 від 29 вересня 1920 р.).

26 Там само. Zespól Akt «SAU». Sygnatura I. 380.1.44. («Наказ...» № 92 від 18 вересня 1920 р.). 
Й. Лаговський, О. Різун, О. Островський, К. Будник ${ }^{27} .19$ вересня з Ланцуту до Місії прибув хорунжий Лощинський - для отримання мотоциклета для потреб Збірної станиці Армії УНР²8.

22 вересня 1920 р. В. Зелінський виїхав до Української збірної станиці у Ланцуті, й далі - до Львова і Ставки головного отамана С. Петлюри (на час його відсутності обов'язки начальника Місії виконував начальник IV-го відділу полковник М. Бондарівський). Від'їзд В. Зелінського ніяк не позначився на роботі Місії, яка продовжувала приймати та відряджати значну кількість старшин, які прибували до Варшави задля вирішення різних службових завдань. В їх числі - командир 1-ої сотні Кам'янецької Юнацької школи Армії УНР поручник Валійський (прибув із метою «ознайомлення з постановленням діла в Польських Юнацьких школах»), урядовець гарматної управи військового міністерства УНР полковник Зайківський («в справі відпущення Польським Міністерством грошей по сметі», начальник Генерального штабу Армії УНР генерал-хорунжий В. Сінклєр, полковник Ющенко, підполковник Нізієнко та ін. ${ }^{29}$

У цей час до польської столиці ледь не щодня прибували уповноважені старшини та військові урядовці - насамперед, у справах виконання заявок частин і з'єднань Армії УНР та отримання військової амуніції. Зокрема, з 25 вересня у польській столиці перебував бухгалтер Військово-санітарної управи головної управи постачання Калиновський, який був відряджений сюди «для захисту потреб Санітарної управи за вересень-грудень», начальник бюджетного відділу Бюджетно-рахункової управи головної управи постачання військового міністерства УНР старший адміністратор Гордовський («для захисту потреб грошей на вересень-грудень») $)^{30}$.

27 вересня до Варшави - для отримання «артилерійського майна» прибув старшина для доручень гарматної управи головної управи постачання сотник Голиков, наступного дня - начальник зв'язку штабу Головної команди Військ УНР поручник Оріх (для отримання від польського командування технічного майна), старшина для доручень головної управи постачання поручник Голян і урядовець Левуцький (3 4-ма

27 Там само. Zespól Akt «SAU». Sygnatura I. 380.1.44. («Наказ...» № 113 від 30 вересня 1920 р., підписаний т.в.о. начальника Місії полковником М. Бондарівським).

${ }_{28}$ Там само. Zespól Akt «SAU». Sygnatura I. 380.1.44. («Наказ...» № 101 від 25 вересня 1920 р.).

29 Там само. Zespól Akt «SAU». Sygnatura I. 380.1.44. («Наказ...» № 92 від 18 вересня 1920 р., підписаний начальником Місії генерал-поручником В. Зелінським; «Наказ...» № 101 від 25 вересня 1920 р., підписаний т. в. о. начальника Місії полковником М. Бондарівським).

30 Там само. Zespól Akt «SAU». Sygnatura I. 380.1.44. («Наказ...» № 101 від 25 вересня 1920 р.). 
козаками) - для отримання різної військової амуніції. 30 вересня до місії прибув старший діловод Військово-санітарної управи військового міністерства УНР Головко («за медикаментами») ${ }^{31}$.

Місія продовжувала опікуватися й військовими інвалідами, прийнявши поручника Чеховського і хорунжого Гальчука, які прибули до Варшави для отримання протезів; допомагала помічнику командира 6-ої Запасової бригади Армії УНР полковнику Васильєву, який перебував на амбулаторному лікуванні у Варшаві, та старшині 2-го кінного Максима Залізняка полку Романченку, який прибув до Варшави за розпорядженням С. Петлюри для проходження лікування в одному 3 варшавських шпиталів. 3 допомоги місії користали й 15 вояків-інвалідів Армії УНР, яких було тимчасово переведено з Ланцуту до Варшави (тут їм було забезпечено харчування та добові) в очікуванні остаточного вирішення своєї долі ${ }^{32}$.

1 жовтня В. Зелінський повернувся з відрядження до Варшави. На нього та очолювану ним Місію чекали чергові завдання i, зокрема, забезпечення охорони державних паперів УНР під час їх експедиції (для цього було притягнуто групу старшин та козаків зі Збірної станиці $)^{33}$. Одним із свідчень успішної роботи місії стала подяка командувача Дієвої армії УНР М. Омеляновича-Павленка, яка була передана телеграфом В. Зелінському, - за раніше відправлену до Дієвої армії партію старшинської зброї та кокарди ${ }^{34}$.

Як і вересень, жовтень 1920 р. видався для Місії дуже насиченим, що було пов'язано, насамперед, із відомими політичними подіями (підписанням 12 жовтня 1920 р. між Польщею і більшовицькою Росією прелімінарної мирної угоди). У зв'язку з цим мала Збірна станиця підлягала фактичній ліквідації, а всі вояки, які там перебували, мали виїхати до свої фронтових частин. Для забезпечення цього виїзду 7 жовтня цього ж року до Станиці відбув сотник Г. Драченко ${ }^{35}$.

Армія УНР готувалася до продовження бойових дій проти більшовиків, польська сторона - хоча й пішла на припинення воєнних дій 3 останніми - продовжувала надавати всебічну допомогу своєму союзнику. У цей час завдяки посередництву Місії до Дієвої армії надходило

31 Там само. Zespól Akt «SAU». Sygnatura I. 380.1.44. («Наказ...» № 113 від 30 вересня 1920 р.).

32 Tам само. Zespól Akt «SAU». Sygnatura I. 380.1.44. («Наказ...» № 107 від 27 вересня 1920 р.).

33 Там само. Zespól Akt «SAU». Sygnatura I. 380.1.44. («Наказ...» № 115 від 1 жовтня 1920 р., підписаний начальником Місії генерал-поручником В. Зелінським).

34 Там само. Zespól Akt «SAU». Sygnatura I. 380.1.44. («Наказ...» № 117 від 2 жовтня 1920 р.).

35 Там само. Zespól Akt «SAU». Sygnatura I. 380.1.44. («Наказ...» № 125 від 7 жовтня 1920 р.). 
все необхідне - від стрілецької зброї до гарматних набоїв, від продовольства - до одягу ${ }^{36}$. Відтак до Варшави продовжували прибувати численні посланці різних частин та структур Армії УНР, аби отримувати та супроводжувати військові вантажі для фронтових частин. Серед них був начальник фармакологічного відділу Військово-санітарної управи військового міністерства УНР сотник Лютий-Лютенко, інженер 2-ої Волинської дивізії сотник Панченко, старшина для доручень при гарматній управі військового міністерства УНР сотник Голиків (знову «за одержанням гарматного майна»), урядовець згадуваної гарматної управи полковник Зайківський і начальник бюджетного відділу управи головного постачання старший адміністратор Гордовський ${ }^{37}$.

Приїзд до Місії секретаря Військової місії УНР у Бельгії сотника Дідуника, а також накопичений обсяг військово-політичної інформації виняткової важливості спонукав В. Зелінського відрядити 10 жовтня сотника Ю. Осецького до Ставки головного отамана ${ }^{38}$. Того ж дня начальник 1-го відділу Місії генштабу підполковник Дідковський відбув у службове відрядження до Риги для участі в конференції Балтійських держав (на виконання доручення голови Ради народних міністрів уряду УНP $)^{39}$.

У наближенні вирішальних для Армії УНР днів Місія продовжувала сплачувати добові воякам (сотнику Коцару, хорунжим Шиліку i Ястрембському), які поверталися після лікування в польських шпиталях та очікували на виїзд до Дієвої армії. Натомість поручник Швидун прибув до Варшави для спеціального лікування, і Місія теж подбала про його розміщення в одному з військових шпиталів та сплачувала йому добові. У середині жовтня до Місії була приряджена вже згадувана лікарка 46-го стрілецького куреня 6-ої Січової дивізії поручник $\mathrm{X}$. Сушко, яка все ще продовжувала перебувати на лікуванні у Варшаві, потребуючи постійного догляду. 3 цією метою до місії прибула сестра-жалібниця Е. Порохняк ${ }^{40}$.

У цей час не зменшувався й обсяг кур'єрів, які прямували до Варшави - у другій половині жовтня до Місії зголосилися начальник за

36 Докладн. про це див.: Срібняк I. Військова співпраця УНР та Польської Республіки у другій половині 1919-1920 рр. ...С. 174-175.

37 WBH CAW. Zespól Akt «SAU». Sygnatura I. 380.1.44. («Наказ...» № 122 від 5 жовтня 1920 р., «Наказ...» № 129 від 9 жовтня 1920 р., «Наказ...» № 131 від 11 жовтня 1920 р.).

38 Там само. Zespól Akt «SAU». Sygnatura I. 380.1.44. («Наказ...» № 129 від 9 жовтня 1920 р., «Наказ...» № 131 від 11 жовтня 1920 р.).

39 Там само..

40 Tам само. Zespól Akt «SAU». Sygnatura I. 380.1.44. («Наказ...» № 125 від 7 жовтня 1920 р., «Наказ...» № 135 від 13 жовтня 1920 р., «Наказ...» № 145 від 20 жовтня 1920 р.). 
кордонного відділу ГУГШ сотник Крижанівський, булавний старшина для доручень 3-го Генерал-квартирмейстера Генерального штабу Армії УНР сотник Луцький, старшина управи технічних військ Дієвої армії сотник Тетятник. Начальник Кам'янецького базисного інженерного складу сотник Пожар (разом із кількома своїми підлеглими) прибув до столиці для отримання технічного майна. 3 цією ж метою тут перебував молодший старшина панцерного потягу «Чорноморець» поручник Кісілів (отримання майна для 1-го Флотського півекіпажа Арміï УНР $)^{41}$.

Ще за 10 днів до столиці Польщі прибули: штаб-старшина для доручень головної управи постачання підполковник Ященко, сотник гарматної управи Сухоцький, інженер головної технічної управи поручник Венке і хорунжий Плавич ${ }^{42}$. Крім того, Місія деякий час сплачувала добові двом старшинам із «Норманської бригади» ${ }^{43}$ (полковнику Гудику i майору Бюргбому $)^{43}$, які провадили переговори про можливе залучення вояків цієї формації до участі у воєнних діях проти більшовицької Pociï.

Отже, проаналізовані у статті документи свідчать, що за весь час свого існування Українська військова місія виконала величезний обсяг роботи, яка полягала, насамперед, у забезпеченні процесу поповнення особового складу Армії УНР. Для цього заходами Місії була організована робота Збірної станиці Армії УНР у Ланцуті, в стінах якої стало можливим забезпечити проходження новобранцями (здебільшого вояками інших національних формацій) короткого вишколу перед їх відправкою до фронтових частин. Важливою складовою цього процесу було національно-патріотичне виховання цієї категорії українського вояцтва, що відбувалося через створені у Станиці культурно-просвітні осередки та завдяки виданню Місією часопису «Син України».

Разом із тим, іï члени докладали всіх зусиль для налагодження поставок зброї для Дієвої армії, провівши з цією метою ряд переговорів із зацікавленими у цьому представниками урядів європейських країн та ділових кіл (з огляду на майже повну відсутність коштів в уряді УНР,

41 Там само. Zespól Akt «SAU». Sygnatura I. 380.1.44. («Наказ...» № 133 від 12 жовтня 1920 р., «Наказ...» № 137 від 15 жовтня 1920 р., Наказ...» № 143 від 19 жовтня 1920 р., «Наказ...» № 149 від 23 жовтня 1920 р.).

42 Там само. Zespól Akt «SAU». Sygnatura I. 380.1.44. «Наказ...» № 137 від 15 жовтня 1920 р., Наказ...» № 143 від 19 жовтня 1920 р., «Наказ...» № 149 від 23 жовтня 1920 р.).

43 Докладн. про неї див.: Кротофіль М. Проект формування Норманської бригади в армії УНР / пер. 3 пол. А. Руккаса // Військово-історичний альманах. 2007. № 1(14) (8 серпня). С. 38-48.

${ }_{44}$ WBH CAW. Zespól Akt «SAU». Sygnatura I. 380.1.44. («Наказ...» № 135 від 13 жовтня 1920 р.). 
організувати придбання значних партій військового майна так і не вдалося). Предметом особливих турбот Місії стало формування у Варшаві автоколони, яка мала посилити бойовий ресурс Дієвої армії. Заходами Miciї був укомплектований водійський та технічний склад автоколони, який перебував на ії утриманні. Крім того, Місія опікувалася усіма військовими кур'єрами, які прибули до польської столиці у службових справах: всі вони зараховувалися на тимчасове грошове забезпечення, отримуючи добові на весь час свого перебування у відрядженні.

Діяльність Української військової місії стала одним із найяскравіших епізодів у польсько-українській військово-політичній співпраці 1920-х - 1930-х років, давши кращі приклади кооперації зусиль двох країн - Польщі та УНР - перед смертельною загрозою з боку більшовицької Росії. Весь час свого існування Місія залишалася центральною зв'язковою ланкою між військовими відомствами і збройними силами двох країн, причинившись (особливо на початках своєї діяльності у якості військової секції) до формування у більшості представників польського військового проводу позитивного сприйняття Армії УНР та iii бойового потенціалу.

Важливим було й те, що після завершення активної фази боротьби з більшовизмом Місія продовжила свою діяльність як Українська військова ліквідаційна комісія (пізніше - як Українська ліквідаційна комісія в справах полонених та інтернованих в Речі Посполитій Польській) та найбільше причинилась до розміщення інтернованої Армії УНР у таборах та організації побуту її вояцтва протягом 1921 р. Таким чином, Місія гідно виконала своє найголовніше завдання - достойну репрезентацію Війська УНР в Польщі та послідовне обстоювання його інтересів.

\section{REFERENCES}

1. Karpus, Z. (1997). Formowanie oddziałów ukraińskich w Polsce w latach 1919-1920. In Z. Karpus, W. Rezmer, E. Wiszka (Ed.), Polska i Ukraina. Sojusz 1920 roku i jego nastęstwa [Formation of Ukrainian troops in Poland in 19191920. In Poland and Ukraine. The alliance of 1920 and its aftermath] (pp. 235-244). Torun. [in Polish].

2. Karpus, Z. (1997). Jeńcy i internowani rosyjscy i ukraińscy na terenie Polski w latach 1918-1924 [Russian and Ukrainian prisoners of war in Poland in 19181924]. Torun. [in Polish].

3. Karpus, Z. (1999). Wschodni sojusznicy Polski w wojnie 1920 roku. Oddzialy wojskowe ukraińskie, kozackie i bialoruskie w Polsce w latach 1919-1920 [Eastern allies of Poland in the war of 1920. Ukrainian, Cossack and Belarusian military units in Poland in 1919-1920]. Toruń. [in Polish].

4. Karpus, Z. \& Sribnyak I. (2000). Formuvannya ziednan Armii UNR u Polshchi v 1920 rr. [Formation of units of the Ukrainian People's Army in Poland in 1920]. Ukrayinskyy istorychnyy zhurnal, 1, 81-89. [in Ukrainian]. 
5. Kovalchuk, M. (2005). Ukrainska vijskova misiya v Polshchi (lypen-lystopad 1920 r.) [Ukrainian military mission in Poland (July-November 1920)]. Ukrayina dyplomatychna, 6, 382-406. [in Ukrainian].

6. Krotofil, M. (2007). Proekt formuvannya Normanskoyi bryhady v armii UNR [The project of forming the Norman Brigade in the Ukrainian People's Army] (A. Rukkas, Trans.). Viyskovo-istorychnyy almanakh, 1(14), 38-48. [in Ukrainian]. 7. Rukkas, A. \& Kovalchuk, M. (2003). Dialnist viyskovoyi sektsii pry Ukrainskiy dyplomatychniy misii u Varshavi (hruden 1919 r. - lypen 1920 r.) [Activities of the military section at the Ukrainian diplomatic mission in Warsaw (December 1919 - July 1920)] Ukrayinska starovyna, 5(353), 128-156; 6(354), 150-158. [in Ukrainian].

8. Rukkas, A. O. (2013). «Razom z polskym viyskom...»: Armia Ukrainskoi Narodnoi Respubliky 1920 r. (struktura, orhanizatsiya, chyselnist, uniforma) [«Together with the Polish army...»: Ukrainian People's Army in 1920 (structure, organization, size, uniform)]. Nizhyn. [in Ukrainian].

9. Rukkas, A. (2018). Polsko-ukrainskyi viyskovyi soyuz 1920 r. [PolishUkrainian military union in 1920]. Abstract of Papers '18: Polsko-ukrayinska viyskova spivpratsya protyahom istorii. Materialy konferentsiyi (pp. 202-233). Kyiv. [in Ukrainian].

10. Rukkas, A. (2019). Stvorennya ta diyalnist orhaniv viyskovodyplomatychnoho predstavnytstva UNR v Polshchi (1919-1921 rr.) [Establishment and activity of the Ukrainian People's Republic military-diplomatic mission in Poland (1919-1921)]. In I. Matyash, V. Sobiyanskyy (Ed.), Ukraina i Polshcha: shlyakhamy mizhderzhavnykh vzayemyn. Zbirnyk naukovych prats $z$ nahody 100-richchya vstanovlennya polsko-ukrainskykh dyplomatychnykh vidnosyn (K. Moskalets, Trans., pp. 89-107). Kyiv. [in Ukrainian].

11. Shumylo, M. (2019). Geneza soyuzu. Vidnosyny Ukrainskoyi Narodnoi Respubliky z Polshcheyu (sichen 1919 - kviten 1920 rr.) [Genesis of the Union. Relations of the Ukrainian People's Republic with Poland (January 1919 - April 1920)]. In I. Matyash, V. Sobiyanskyy (Ed.), Ukraina i Polshcha: shlyakhamy mizhderzhavnykh vzayemyn. Zbirnyk naukovych prats z nahody 100-richchya vstanovlennya polsko-ukrayinskykh dyplomatychnykh vidnosyn (K. Moskalets, Trans; pp. 36-53). Kyiv. [in Ukrainian].

12. Sribnyak, I. (1995). Symon Petlura na choli derzhavy ta viyska. Do pytannya pro polsko-ukrainski vzayemyny 1919-1920 rokiv [Simon Petlura at the head of the state and the army. On the question of Polish-Ukrainian relations in 1919-1920]. Zbirnyk prats druhoho konkursu petlyuroznavtsiv Ukrayiny, 137-164. Kyiv. [in Ukrainian].

13. Sribnyak, I. (2018). Viyskova spivpratsya UNR ta Polskoyi Respubliky u druhiy polovyni 1919-1920 rr.: orhanizatsiyno-mobilizatsiynyy aspekt [Military cooperation of the Ukrainian People's Republic and the Republic of Poland in the second half of 1919-1920: organizational and mobilization aspect]. Abstract of Papers '18: Polsko-ukrainska viyskova spivpratsya protyahom istorii [PolishUkrainian military cooperation throughout history]. Materialy konferentsiyi (pp. 151-176). Kyiv. [in Ukrainian].

14. Sribnyak, I. (2018). Nepokazna zvytyaha (kilka epizodiv z zhyttya poruchnyka Armiyi UNR, likarya Khrystyny Skachkivskoyi-Sushko, 19191925 rr.) [Inconspicuous victory (several episodes from the life of a lieutenant 
of the Ukrainian People's Army, medical doctor Khrystyna Skachkivska-Sushko, 1919-1925)]. Nashe zhyttya, LXXV(1), 13-16. [in Ukrainian].

Ihor Sribnyak

Doctor of Sciences (History), Professor, Head of the Department of World History

Historical-philosophical faculty,

Borys Grinchenko Kyiv University

ORCID: https://orcid.org/0000-0001-9750-4958

\title{
ON THE HISTORY OF UKRAINIAN MILITARY DIPLOMACY IN POLAND IN 1920 \\ (according to the documents of Centralne Archiwum Wojskowe)
}

\begin{abstract}
The aim of the article lies in incorporating unpublished archival documents preserved in the Central Military Archives of Poland (Centralne Archiwum Wojskowe) to the scientific narrative. These documents are a unique source for presenting general trends of activity of the Ukrainian Military Mission in Poland (May - October 1920). The research methodology is based on adherence to the principles of historicism, anthropology, civilizational, synergic, and systematic approaches along with the usage of analysis and synthesis methods as well as comparative methodology. The scientific novelty lies in the unique source value of the aforementioned documents that contain a considerable number of references on the Ukrainian People's Army foremen and military officials' surnames who arrived in Warsaw due to various means of official business. In addition, the orders captured information about multiple business trips, sometimes along with mentioning their purpose and travel destination. In certain circumstances, the orders of the Mission reconstruct fragments (or the entirety) of the Ukrainian People's Army higher military institutions' instructions. Conclusions. The analysis of orders undertaken within this article shows that, throughout its whole existence, the Ukrainian Military Mission implemented an enormous amount of work which preeminently was based on maintaining personnel replacement of the Ukrainian People's Army. Simultaneously, its members undertook all necessary efforts to organize weapon supply for the Ukrainian People's Army which resulted in the set of discussions with interested powers among the governmental representatives of the European states and business circles. The activity of the Ukrainian Military Mission has become one of the most vivid episodes of the joint Polish-Ukrainian military cooperation in the 1920s-1930s that provided the best examples of uniting together efforts of two countries - Poland and Ukraine - in front of deadly danger from Bolshevik Russia. The whole period of Mission's existence was marked by its remaining as a central communication detachment between the military establishments and armed services of two states that led to the formation of a majority of Polish military representatives who positively perceive the Ukrainian People's Army and its combat potential.
\end{abstract}

Key words: Ukrainian Military Mission; order; courier; business trip; Ukrainian People's Army; Poland; Polish-Ukrainian cooperation. 